\title{
Differentiating Instruction: Development of a Practice Framework for and with Secondary Mathematics Classroom Teachers
}

\author{
Andrew Marks ${ }^{1}\left(\mathbb{D}\right.$, Geoff Woolcott ${ }^{1^{*}}$ D, Christos Markopoulos $^{1}$ (D)
}

${ }^{1}$ School of Education, Southern Cross University, AUSTRALIA
${ }^{\star}$ Corresponding Author: geoff.woolcott.mnl@outlook.com

Citation: Marks, A., Woolcott, G., \& Markopoulos, C. (2021). Differentiating Instruction: Development of a Practice Framework for and with Secondary Mathematics Classroom Teachers. International Electronic Journal of Mathematics Education, $16(3)$, em0657. https://doi.org/10.29333/iejme/11198

\section{ARTICLE INFO}

Received: 6 Apr. 2021

Accepted: 10 Aug. 2021

\begin{abstract}
This article outlines an approach to bridging the gap between the theory and practice of differentiated instruction. Differentiated instruction has long been suggested as a pedagogical approach to cater for student individuality and diversity, particularly in mixed-ability classrooms. Although the theory of differentiated instruction has been applied widely, such instruction has not been taken up widely in teaching practice. The first part of the article explores the relationship of theory and practice of differentiated instruction in relation to pedagogical content knowledge, teacher efficacy, formative assessment, teacher confidence and competence and professional learning. This exploration uses exemplar cases from mathematics teaching to pave the way for an outline, in the second part of the article, of how differentiated instruction could be implemented for the mixed-ability groupings increasingly engaged in the Australian secondary mathematics classroom. A protype practice framework for teachers is presented as part of a project being conducted in regional Australia, with the overall aim of assisting teachers in developing and implementing strategies for differentiated instruction in secondary mathematics classrooms.
\end{abstract}

Keywords: differentiation, differentiated instruction, differentiating the curriculum, theory and practice; practice framework, evidence-based practice

\section{INTRODUCTION}

A teacher's ability to effectively differentiate instruction in the classroom is crucial in catering for student individuality and diversity, especially in the context of inclusive learning-differentiated instruction is aimed at optimising the educational outcomes for all students (Banks, 2007; OECD, 2010, 2018; Tomlinson, 2004, 2005; UNESCO, 2005, 2015). Tomlinson (2003, 2014) defines differentiated instruction as a pedagogical approach where teachers modify curriculum content, proactively develop a variety of teaching strategies and continually revisit the desired product of learning. On this basis, the goal of the teacher in a differentiated classroom is to allow students to make connections with their prior learning and build upon their knowledge quickly and efficiently.

The most common approach used to address diverse learning needs, both nationally and internationally, is to place the students into homogenous ability groupings using a selection process known as 'streaming', 'setting' or 'tracking' based on attainment grouping (Francome \& Hewitt, 2020; Jaremus et al., 2020). There is a growing body of research, however, that has cast doubt on the usefulness of attainment grouping, including studies from the United Kingdom and the United States as well as from the Asia-Pacific region and western Europe (e.g., Francis et al., 2019; Francome \& Hewitt, 2020; Gamoran, 2009; Mijs, 2016; Murata, 2013; Taylor et al., 2017, 2020). In the Australian context, Johnston \& Wildy (2016, p. 42) have noted that: "While research is contentious and often contested, the literature generally shows that streaming impacts negatively on student learning outcomes." In mathematics, for example, the disadvantages for students placed in the lower ability groupings include becoming disengaged, as grouping practices often serve to entrench student interest and performance from primary school-students in a low or middle mathematics ability group face a 'glass ceiling' concerning mathematics studies, especially in senior years (Jaremus et al., 2020). Boaler et al. (2000) found that there were also disadvantages for students placed in the highest ability groupings due to the high expectations placed on them, the fast pace of the lessons, and the pressure to succeed, with the ablest girls being most affected.

The most common flexible-grouping alternative is heterogeneous or mixed-ability grouping (called 'detracking' in the USA, see Tereshchenko et al., 2019), which assembles a mixture of abilities in the same classroom. Such groupings aim, amongst other things, to create a well-rounded blend of all levels that allows higher achieving students to mentor their peers in a supportive and cohesive environment, fostering self-esteem and promoting the concept of inclusive education (Cohen \& Lotan, 2014; Ireson et 
al., 2002). Such heterogeneous grouping also serves to avoid teachers' predilections with a particular biases or 'mind-set' sometimes attributed to homogenous groupings (e.g., see Dweck, 2008; Easterbrook \& Hadden, 2021). The downside of a mixed ability setting, typical of a heterogeneous classroom, is that its success is reliant on teachers adjusting curriculum, materials, and support to provide equal opportunities for all students in order to ensure their progression academically, socially, and emotionally (Valiandes \& Neophytou, 2018).

Differentiated instruction offers a way to embrace the advantages of a heterogeneous grouping. Such instruction offers elements that foster positive learning environments, embracing diversity in a way that provides for individual growth in learning based on a student's ability, interest and readiness levels (Tomlinson, 1999). Despite its importance, however, the research on how instruction can be differentiated for classroom students is diffuse. In the United States, for example, the discussion may be embedded in "what mathematics is important for whom and who decides; how people can effectively teach and learn mathematics" (Raymond, 2018, p. 1). In that particular context, there has been a focus on models of instructional design that broaden the purpose of education, including those that advocate inquiry-based learning (e.g., Boaler, 1997) or where instructional design is based on a well-researched human cognitive architecture (Sweller et al., 2011), but not models specifically dedicated to differentiated instruction for mixed-ability groupings.

This article, therefore, explores the relationship of theory and practice of differentiated instruction and, as well, explores how this relationship can be used to assist improve teachers in understanding how to bridge the gap between theory and practice in order to become more effective in differentiating instruction in the classroom. The first part of the article explores the relationship of theory and practice in relation to pedagogical content knowledge, teacher efficacy, formative assessment, teacher confidence and competence and professional learning. Although many such discussions are concerned with empowering student learning, and move away from a whole-class didacticism, there are few studies that report on differentiated instruction that has been implemented successfully in a secondary mathematics classroom (see e.g., Sullivan et al., 2020). The exploration of theory and practice, therefore, uses exemplar cases from secondary mathematics teaching to pave the way for an outline, in the second part of the article, of how differentiated instruction could be implemented for the mixed-ability groupings increasingly engaged in the Australian secondary mathematics classroom. The second part of the article focuses on how to improve the ability and motivation of mathematics teachers to implement curriculum differentiation effectively and sustainably and to thereby provide a new model of learner engagement to redress current shortcomings.

With this focus in mind, the article presents a novel approach, built around a prototype practice framework, that should enable mathematics teachers, regardless of teaching experience, to progress on a continuum of practice, leading to differentiated instruction that is integral to their teaching. The practice framework acknowledges the secondary mathematics classroom as a complex environment (Davis \& Renert, 2013) and, therefore, engages a set of boundary conditions drawn from a successful blueprint for differentiating instruction (Rock et al., 2008) and from the strategic focus of the guiding questions that form the basis of generative dialogue (Adams et al., 2019). The initial framework uses these boundary conditions to form the basis for beginning the co-development and professional learning typical of the informed iterations of design-based implementation research (DBIR) approaches (Fishman et al., 2013; Woolcott et al., 2019a).

The article outlines a pragmatic and practicable 'whole-school' approach (Ohi et al., 2019) designed to transform mathematics education by leveraging recent progress in bridging the gap between theory and practice. The framework, therefore, has been developed so that it can be implemented using collaboration and co-creation (Woolcott et al., 2019s, 2019b). The combination of iterative processes and co-development should enable teachers and students to forge new understandings and perspectives of the value of differentiated instruction, as well as providing active participation in, and reflection on the learning and teaching of secondary mathematics.

\section{THE EMERGENCE OF DIFFERENTIATED INSTRUCTION}

In high school classrooms across the globe, it is common practice to place students into broad learning streams, for example, high achieving student who are exposed to extension activities, middle band students who complete the standard curriculum, and lower-achieving students for whom curriculum demands are adjusted down (e.g., OECD, 2013). The underlying principle behind streaming is to make teaching more effective-in terms of outcomes for students-making the curriculum better suited to their level of understanding, but also in terms of making the planning and delivery of a lesson more streamlined for the teacher (Johnston \& Wildy, 2016).

Streaming, however, may have a negative impact on students, academically, socially, and emotionally, with a more significant impact on lower-achieving students, for example, in terms of mathematical literacy (Razer et al., 2018). In secondary mathematics, the disadvantages for students placed in the lower ability groupings include becoming disengaged, with grouping practices serving to entrench student interest and performance starting in primary school. Students in a low or middle ability grouping, for example, face a 'glass ceiling' concerning mathematics studies, especially in senior years (Jaremus et al., 2020). Boaler et al. (2000) found that there were also disadvantages for students placed in the highest ability groupings due to the high expectations placed on them, the fast pace of the lessons, and the pressure to succeed, with the ablest girls being most affected. Students in a heterogeneous mathematics classroom setting, for example, learn more, enjoy mathematics more, and achieve a higher level of understanding (Boaler \& Staples, 2008).

In many countries, however, heterogeneous grouping is not widely adopted. For example, approximately $98 \%$ of Australian secondary schools adopt some form of ability grouping, a significantly higher figure than the OECD average of 75\% (OECD, 2013). There may be several reasons for this, but one issue may be that the success of the mixed-ability setting is reliant on teachers 
adjusting curriculum, materials, and support to provide equal opportunities for all students in order to ensure their progression academically, socially, and emotionally (Francome \& Hewitt, 2017; Tereshchenko et al., 2019; Valiandes \& Neophytou, 2018). There is also compelling complementary evidence that teachers can, but may be unwilling to, effectively deliver learning outcomes from curriculum within a differentiated classroom (e.g., Smale-Jacobse et al., 2019; Tomlinson, 2014).

The notion of differentiated instruction, particularly as it is applied to heterogeneous groupings, was developed in large part along with theoretical changes in education and pedagogy in the 1970s and 1980s, such as those espoused by such constructivistaligned luminaries as Piaget and Vygotsky (see e.g., Kalina \& Powell, 2009; Suprayogi et al., 2017). Consequently, classroom teaching (at least in developed and developing regions) became focussed on the idea that opportunities for meaningful learning can be achieved by establishing what students already know and then presenting new information in such a way that students can create their own meanings (Bada, 2015; Brooks \& Brooks, 1999). This idea is reflected in the modern secondary mathematics classroom, where differentiated instruction is considered as proactively adapting instruction to suit the mathematical thinking of students while concurrently developing a cohesive classroom environment (Hackenberg et al., 2020).

The flawed relationship between theory and practice in relation to differentiated instruction, however, extends across notions such as pedagogical content knowledge (PCK), teacher efficacy, formative assessment, and teacher confidence and competence. PCK plays a vital role in a teacher's ability to differentiate instruction (Gess-Newsome, 2015) and the lack of PCK will adversely affect a teacher's ability to be flexible with the delivery of content and adapt to the individual needs of students (Davis \& Renert, 2013; Woolcott et al., 2019b). Dixon et al. (2014) argue that teacher efficacy (a teacher's belief or judgement of their own capabilities) underpins the ability to differentiate instruction effectively, with efficacy dependent on PCK. Effective differentiation of the curriculum is also underpinned by formative assessment, which offers the teacher insight into what students already know and what they need to know (Bond et al., 2020; Tomlinson, 2014). Formative assessment provides information about the learning process that informs instructional decisions made by the teacher and encourages students to improve their performance (Wiliam, 2011). Teacher PCK, efficacy and teacher knowledge of formative assessment are closely linked to teacher confidence, that is, how a teacher perceives his or her own performance, as well as teacher competence (Woolcott et al., 2017a, 2017b, 2019b).

Active professional learning may be a way for teachers to improve their practice of differentiated instruction by developing relevant knowledge, skills and experience (Bui et al., 2020). The preferred terminology used to describe this learning has changed over the years, with professional learning superseding previously used terms such as teacher in-service and professional development (Bobis et al., 2020). Research has shown traditional forms of professional learning, such as conferences and short workshops (sometimes referred to as professional development), can be useful in assisting teachers in developing their skills and knowledge, but that they do not lead to a sustainable change in teacher practice. To learn new knowledge and skills for differentiated instruction, teachers must, therefore, participate in a well-structured professional learning program (Valiandes \& Neophytou, 2018).

The notion of differentiated learning arose largely in response to an overreliance on didactic teaching methods (Mayer-Smith \& Mitchell, 1997; Valiandes \& Neophytou, 2018) and the conceptualisation of differentiated instruction developed in large part in an environment where constructivism (the constructivist theory of learning) predominanted (Suprayogi et al., 2017). Constructivism argues that individuals develop and refine their understandings and knowledge through the interaction of what they already know and believe and the activities and interactions they encounter, rather than through the passive transfer implied in purely didactic approaches (Lunenburg, 2011; Ültanır, 2012). Cooper (2007) characterises constructivist pedagogy as having three principles: 1) the use of prior knowledge to facilitate new learning; 2) active participation in the learning process; and, 3) the continual development of expertise. This type of pedagogy helps to develop 'lifelong learners' by promoting the virtues of a student's search for meaning as much as the knowledge gained from that search (Cooper, 2007).

Two of the most important modes of constructivist thinking are Piaget's (1972) individual (cognitive) constructivism and Vygotsky's (1978) social cognitive constructivism. Piaget's (1972) constructivism centres on individuals constructing a schema in the process of their learning-students need to process new information in a way that aligns with prior learning, facilitated by the teacher, in order to conceptualise schemas through assimilation (recognising a situation) and accommodation (adapting to an unexpected outcome) (Kalina \& Powell, 2009; Von Glasersfeld, 1998). Vygotsky's (1978) theory of social cognitive constructivism centres around his notion of a zone of proximal development (ZPD) (see e.g., Siyepu (2013) for application in mathematics), with learning summarised as "figuring out how to use what you already know in order to go beyond what you currently think" (Bruner, 1984, p. 183).

Although Piaget's (1972), and Vygotsky's (1978) views may seem divergent, both consider that students obtain meaning because their learning allows them to construct their knowledge either individually or in social groups (Lerman, 2012). A constructivist classroom aims to provide a supportive and accepting atmosphere where the teacher guides students through a process of inquiry, which eventually leads to each student achieving their potential (Gregory \& Chapman, 2013; Kalina \& Powell, 2009).

Achieving a productive constructivist environment is possible by facilitating activities that require both individual 'discovery' learning as well as inquiry and social interaction in the classroom (Tomlinson et al., 2003). Students and teachers involved in such an environment will benefit from this dynamic and effective learning atmosphere (Lerman, 2012). Tomlinson et al. (2003) state that teachers must respond to student readiness, interest, and learning profile and consistently, defensibly, and vigorously adjust curriculum and instruction to cater to the needs of all students. This differentiation of instruction will encourage the students to be actively engaged in their learning, which will allow them to build on prior knowledge, transfer knowledge and build a deeper understanding of the curriculum, which are the core principles of a constructivist learning environment (Tomlinson, 2017).

The teacher's role in the constructivist environment is to facilitate activities that start from what the students can already achieve through prior knowledge, and provide links to activities that require support, a theme later taken up in the instructional 
design conceptualisations of cognitive load theory (CLT) (Sweller et al., 2011). CLT focuses on human cognitive architecture seen in terms of a large long-term memory constrained by attention and working memory in ways that contribute to cognitive load or mental effort (see also Kalyuga, 2015). CLT provides a suitable framework for differentiated instruction, as it takes this cognitive architecture into account when designing lessons and linking new information with prior knowledge, a priority in the constructivist view. CLT, as well as taking into account cognitive differences between individuals, however, also takes into account differences in student interest and learning profiles as intrinsic to differentiating instruction through a suitable instructional design (Kalyuga, 2015; Smets et al., 2020).

\section{Towards Teacher Efficacy}

A lack of Pedagogical content knowledge (PCK) may be affecting the ability and motivation of mathematics teachers to implement differentiation practices effectively and sustainably. In Australia, PCK seems particularly relevant as an issue considering that, in 2018, $45 \%$ of surveyed secondary school principals reported that there were mathematics and science classes taught at their school by a teacher not fully qualified in the subject area (AMSI, 2020).

Shulman (1986) defines PCK as a teacher's ability to understand what makes the learning of a particular concept easy or difficult, and the conceptions and preconceptions that students have when introduced to new content, both of which are central to the quality of teaching in a content area. With regard to teaching mathematics, Ball et al. (2008) developed a practice-based theory based on Shulman's (1986) idea of PCK, defining the mathematical knowledge for teaching (MKT) as the mathematical knowledge required to carry out teaching mathematics. Ball et al. (2008) grouped PCK into two categories: 1) knowledge of content and students (KCS), which combines knowledge of mathematics and knowledge of students, and requires the teacher to focus on what the students are likely to think and what they will find confusing; and, 2) knowledge of content and teaching (KCT), which combines knowledge of mathematics and knowledge of teaching, which requires teachers to consider the design and sequence of their instruction. A third category, knowledge of curriculum (KC) was included by Hill et al. (2008), with all three categories considered under the umbrella of MKT. Goos (2016) views KC in mathematics as teacher knowledge about organisation of conceptual scaffolding within subjects, undertaken in order to cater for increasing complexity in learning during schooling.

Even though teachers understand the importance of differentiation and can identify diversity in their classrooms, they may not be able to translate theoretical concepts, such as PCK and MKT, into practice. For example, Cross (2009) found that teachers' beliefs about mathematics significantly impact the way they plan and deliver their lessons. Teachers' mathematical beliefs were viewed as potentially a cohesive structure where a teacher's beliefs about the nature of mathematics were connected with PCK and student learning and beliefs. This connection may affect the willingness of mathematics teachers to incorporate differentiated instruction in their teaching. For example, De Neve et al. (2015) found teacher self-efficacy as a predictor of beginning teachers reporting improvement in their ability to differentiate instruction-teachers with confidence in their ability to recognise and respond to the learning needs of students can modify and adapt their instructional methods to meet the students' needs. Even when a particular strategy for differentiated instructional fails, these teachers will persist in finding another successful approach to accommodate the needs of the student (De Neve et al., 2015).

Dixon et al. (2014) proposed that teachers who lack confidence in PCK in their content area are less able to be flexible with their delivery of content and, therefore, are less likely to adjust lessons to the needs of their learners. Their lack of efficacy in promoting student learning means that providing differentiated instruction for different groups of learners is a skill they do not think they have-they may focus on how such instruction will fail, or they may feel overwhelmed by the effort required (Dixon et al., 2014). Such efficacy affects how learning opportunities are perceived, choice of activities, time spent on an activity, and the level of persistence when confronted with obstacles (Bandura, 1977). Although teacher efficacy is sometimes seen as a teachers' belief in their ability to actualise the desired outcome (Wheatley, 2005), teacher efficacy is quite commonly confused with actual teaching effectiveness. The beliefs of teachers, however, serve as a filter for knowledge and experience, guiding their decision making and influencing their actions in the classroom (He \& Levin, 2008).

\section{The Role of Formative Assessment}

In undertaking differentiated instruction, a teacher's reliance on feedback from each individual becomes critical and formative assessment must be used in a consistent and persistent way to ensure that each student is progressing "toward and beyond designated learning outcomes" (Tomlinson, 2000). Different levels of support rely on determinations made through such formative assessment and these, in turn, act to guide the identification of any future adapting of instruction for learning while maintaining sight of curriculum goals (Levy, 2008; Smit \& Humpert, 2012).

The purpose of formative assessment in the secondary mathematics context, therefore, is to provide teachers with insight into what their students already know, allowing them to cater to their individual needs through differentiated instruction. Formative assessment is a learning process in which teachers actively and intentionally work with their students to gather evidence of learning to improve student outcomes (Moss \& Brookhart, 2019). Once a teacher has an understanding of what a student holds as 'given' or 'known', they can ensure that each student receives an appropriate task at the right time (Earl, 2012). Tomlinson (2016) argues that formative assessment aligned with content goals provides immediate insight into student understanding and allows the teacher and student to adjust accordingly to facilitate the progression of learning-formative assessment is a bridge between "today's lesson and tomorrow's".

Formative assessment has the potential to contribute significantly to student outcomes and is a critical element of teacher practice (Andersson \& Palm, 2018; Bond et al., 2020). However, despite much research indicating that formative assessment can lead to improvements in student achievement and that it plays a critical role in a teacher's ability to differentiate instruction, the 
suggested outcomes in research-and resulting teacher understanding of formative assessment-have not been achieved due to a lack of effective implementation (Andersson \& Palm, 2017; Bennett, 2011; Black, 2015).

Numerous issues make the effective implementation of formative assessment difficult for teachers. Firstly, formative assessment is a complex, demanding and challenging process, and using assessment information to adjust subsequent learning to meet student needs is extremely difficult (Vingsle, 2014). Secondly, a focus on examinations and other forms of summative assessment may hinder the implementation of formative assessment-perceived accountability and limited time to deliver the curriculum may force teachers to focus their attention on summative assessment only (Andersson \& Palm, 2018). Thirdly, teachers who have attempted formative assessment without sufficient understanding or effective strategies may find no value in that assessment process and, therefore, will be less likely to attempt it in the future (Andersson \& Palm, 2018).

In the Australian educational context, Van der Kleij et al. (2018) have noted that formative assessment is a policy pillar of educational significance, strongly advocated as a crucial element of a teachers' work. However, they found that support for teachers that will lead to effective implementation is inadequate, and any curriculum reform that fails to embed formative assessment with curriculum will not lead to improvements in student learning. Due to the lack of formative assessment guidance, teachers are not encouraged and supported to implement world-class formative assessment practices that are known to be effective. Additionally, formative assessment in the curriculum is little more than a formal statement of significance and general principles (see discussion in Bond et al., 2020).

Wiliam (2011) states that there are three types of feedback that are essential for formative assessment, especially in the differentiated classroom. These include teacher to student, student to teacher, and student to student feedback, and thoughtful use of all three will have a positive effect on learning. For this feedback to occur, adherence to the following five principles of learning is needed.

1. Teachers need to start from where the learners are, which allows them to reconstruct their thoughts and ideas to process new information and deepen their understanding.

2. Students need to be active in learning, and learning cannot be done for them; it has to be done by them.

3. Students need to talk about their ideas, which encourages them to use and construct the language of mathematics.

4. Students need to understand the learning intention of the lesson and have a sound idea of the success criteria.

5. Feedback to the students should be specific and inform them of what they need to do to improve.

These principles make significant demands on teachers' subject knowledge, not only to understand what students are saying but also to determine the appropriate path forward for the student (Hodgen \& Wiliam, 2006).

\section{Teacher Confidence and Competence}

1. The twin notions of teacher confidence and competence are critical in a teacher's identity as a mathematics teacher and understanding these two notions is important in any move a teacher may make towards a focus on differentiated instruction. Confidence is delineated as a positive self-belief concerning a teacher's ability to use PCK to deliver a mathematics lesson in an engaging and influential manner-in other words, a teacher's confidence in knowledge of teaching (see e.g., the MKT of Ball et al. (2008)). Confidence includes perceived competence, a self-efficacy measure, and this can be seen as separate from professional competence, the measure of actual classroom performance (Hatlevik, 2017).

2. Teacher competence, therefore, can be separated from teacher confidence on the basis that competence is best understood in terms of the demonstration of the knowledge required to teach accurate content as well as the demonstration of the pedagogical skills required to teach effectively (Woolcott et al., 2017a, 2017b, 2019b). Competence, therefore, is viewed as not only including PCK, but also as a willingness to be 'ready, willing and able to learn' from teaching experiences (Shulman \& Shulman, 2004) in order to make that teaching effective. Darling-Hammond (2010) has argued for competence as one of a range of 'broader professional and affective attributes' of which confidence is part.

3. A recent Australian study (Woolcott et al., 2017a, 2017b, 2019b) showed that, for pre-service mathematics teachers at least, confidence and competence can be enhanced through a process of non-judgemental scaffolded reflection. The study's explorations of teacher emotional literacy were represented in terms of the affective-reflective skills that a teacher possesses which encompass their emotional understandings and regulation, which have an effect on teacher confidence and which a teacher needs to possess for establishing supportive learning environments (Bleakley et al., 2021; Hawkey, 2006; Sutton \& Wheatley, 2003).

4. Woolcott and colleagues (2017a, 2017b, 2019b) engaged an iterative process that was structured to develop pre-service teachers' awareness of their emotions and, with guidance and support from observers, to increase positive teaching experiences that create confidence and change negative behaviours and frames of mind. Over 55 trials were conducted to improve pre-service teacher competence and confidence through iterations based on lesson study and DBIR approaches that allowed for review and improvement progressively across trial cycles. The study findings support studies that argue strongly for engaging teachers in professional learning programs that utilize processes designed to improve teacher confidence through a combined focus on affect and reflection in developing emotional literacy (Bleakley et al., 2021; Doig \& Groves, 2011; Nichols et al., 2017; Woolcott et al., 2017a, 2017b, 2019b).

5. The importance of preparing reflective teachers is well recognized in the literature and many of the benefits associated with reflective practice may also contribute to the development of greater teaching confidence and improved classroom learning (Harrison \& Yaffe, 2009; York-Barr et al., 2006). This view builds on early studies of Schön and colleagues (e.g., Schön, 1987, 1991) of reflective practice as 'reflection-in-action' in a mentor-teacher context and is supported by 
arguments that reflective practice can be taught (Russell, 2005). In mathematics, for example, reflective practices allow teachers to shift their thinking from a teaching focus to a learning focus where they observe the mathematical thinking during a given situation (Cooper et al., 2017; Graven, 2004).

\section{Teacher Professional Learning and Differentiated Instruction}

The competencies that students require in preparation for further education and employment in the $21^{\text {st }}$ century are becoming progressively more complex, especially in relation to mathematics and allied STEM competencies (Beswick \& Fraser, 2019). Teacher pedagogy, therefore, needs to be adapted and improved upon to develop relevant student competencies, such as mastery of content, problem-solving, critical thinking, working collaboratively with effective communication, and self-directed learning. Timperley (2011) proposes a shift from professional development, in which the primary focus is on developing professional skills, knowledge, and expertise, to professional learning, where the focus is on developing the capacity of the teacher, and which may lead to actual changes in practice that promote these competencies. In turn, effective professional learning is required to help teachers develop and refine the pedagogies needed to teach these skills (Goos et al., 2018).

Many of the professional learning opportunities provided to teachers, however, are ineffective and result in no lasting pedagogical change (Darling-Hammond et al., 2017). While traditional forms of professional learning, such as conferences and short workshops, can assist teachers in developing their PCK and efficacy, professional learning that is sporadic and disconnected is known to be ineffective in the long term, resulting in little change in teachers' beliefs and practices or improvements in student achievement (Boyle et al., 2005; Darling-Hammond et al., 2017; Koellner \& Jacobs, 2015). The following seven widely shared features of effective professional learning are summarised from Darling-Hammond et al. (as professional development, 2017).

1. A focus on content, with particular attention on effective strategies to teach the content.

2. Active learning that engages the teachers in interactive experiences as opposed to the traditional lecture-style of professional learning, which is not typically engaging.

3. Teacher collaboration that supports a togetherness mindset and allows for the development of collective knowledge and extends beyond individual experiences in the classroom.

4. Effective practice that is modelled to enable teachers to see instructional methods in action, whether it be via a video, demonstration lessons, peer observations, or case studies of teaching.

5. The provision of ongoing coaching and expert support that assists teachers in implementing new tools and or curricula while providing the necessary feedback on effectiveness.

6. Feedback and reflection that allows time for teachers to think about, receive input on, and make changes to their teaching practice.

7. Professional learning that is job-embedded and ongoing to allow teachers to engage in cycles of continuous learning.

Differentiated instruction is a complex process and relies on strong and skilful teachers to plan and teach different levels of the same content at the same time. Dixon et al. (2014) found that, although teacher preparation programs should be a natural fit for learning how to differentiate instruction for mixed abilities, they often only provide an introduction to the theory. These cursory glimpses may not offer enough depth to enable teachers to embed the practice, and that ongoing professional learning for teachers is critical in the process of differentiating instruction. Dixon et al. (2014) argue that, if a school is willing to devote time and money to educate staff on differentiated instruction through the engagement of consultants and workshops, then it follows that they should be vigilant in ensuring that the theory becomes practice in the classroom. Allowing teachers to observe the differentiating practices of each other and provide feedback after the observation, for example, as well as providing time for teachers to collaborate on shared lessons, will reinforce teachers practice of what they have learned (Dixon et al., 2014).

There is some evidence to support this argument, with a study by Valiandes and Neophytou (2018) examining the characteristics of a teacher's professional learning program specifically focussed on supporting teachers with the design and application of differentiated instruction. These researchers found that teachers who participated in a well-planned and systematic program were able to connect theory with their everyday practice and successfully differentiated instruction for their students. The key characteristics of the program are summarised from Valiandes and Neophytou (2018) as follows.

1. responding to teacher's needs by providing a program that focussed on both content and pedagogical knowledge;

2. ensuring that the program is of sufficient duration;

3. the initial training and the follow-up support;

4. effective collaboration with colleagues and experts;

5. continuous on-site support; and,

6. the development of personal skills for reflection and self-evaluation.

The study revealed that, through a well-structured training program, the skills and knowledge required to differentiate instruction could be learned, established, and developed, with consequent positive effects on student outcomes.

\section{THE DEVELOPMENT OF A PRACTICE FRAMEWORK}

This second part of the article draws from a study that explores the extent to which mathematics teachers are supported in regional Australia, including support that provides professional learning for differentiated instruction (e.g., see Bui et al., 2020; 
Lynch et al., 2020; Woolcott et al., 2021). The study examines specifically approaches that cater for the needs of mathematics teachers in relation to the development of PCK and teacher efficacy, with an additional focus on formative assessment under the umbrella concepts of teacher confidence and competence (Willis et al., 2021). The current article outlines the design and development, within the broader study of a practice framework for differentiated instruction in mathematics as a prototype whose use would support teachers in the secondary mathematics classrooms.

In the secondary mathematics classroom, as in classrooms more generally, differentiated instruction is a vital component of inclusive education-all students are considered mathematical thinkers and receive the instruction needed for learning (Tomlinson, 2017). A differentiated mathematics classroom is cohesive, where the students work closely with the teacher and celebrate the diversity within, and where the teacher adapts instruction, posing to students the problems and challenges that are aligned with, and at the edge of their thinking (Hackenberg et al., 2020). The remainder of this article describes the development of a practice-based approach, including a practice framework constructed to assist secondary mathematics teachers in developing and implementing effective and sustainable strategies for differentiated instruction.

The framework was designed specifically to assist teachers by: 1) explaining the theoretical basis of differentiated instruction in a way that is relevant to their classroom practices (e.g., How is it an improvement on what I am doing now?); and, 2) examining the various ways that they can implement differentiated instruction (How does it work in my classroom?). The initial intention in using the framework is to encourage teachers to collaboratively re-design, develop, and implement differentiated instruction in the secondary mathematics classroom. In this way, teachers should gain a deeper understanding of the core principles underlying differentiated instruction and gain respect for its necessity in mathematics education, but also see how such instruction can benefit them and their students in mixed-ability classrooms.

By having mathematics teachers actively participating in the research, design and implementation of a practice framework, the approach outlined here helps to overcome the issues around self-efficacy and beliefs, boosting confidence and competence. Hence, the approach supports teachers as active participants, engaging collaboratively in professional learning about differentiated instruction and trialling and evaluating practices in their own school context. This professional learning process should allow teacher knowledge and capacity to be developed on an 'in-school' basis, thus avoiding the difficult task of translating external professional learning to their specific school context. The continual co-development of a co-created framework should then contribute to an agreed shared practice of differentiating instruction in mathematics within the school.

The overall process, as envisaged here, is supported by four guiding principles of differentiated instruction, summarised from Tomlinson (2003, 2014).

1. A focus on the essential ideas and skills in each content area.

2. Responding to individual student differences.

3. Using formative assessment to guide practice.

4. Ongoing adjustment of content, process and product to cater to the individual needs of the student.

Implementing the practice framework would, therefore, also consider seven basic beliefs regarding curriculum differentiation, also summarised from Tomlinson $(2003,2014)$.

1. Same age students vary significantly in their life circumstances, past experiences and their willingness to learn.

2. These differences have a direct impact on the content and pace of instruction.

3. Student learning is improved when they are provided support from the teacher and encouraged to work slightly above what they can do independently.

4. Student learning is enhanced when there are connections made between what they are learning at school and real-life experiences.

5. Authentic learning opportunities strengthen understanding.

6. Student learning is improved when they feel that they are a respected member of the class and the whole school community.

7. The overarching goal of a school is to recognise and promote the individual abilities of each student.

Despite the publication of such guiding principles and beliefs, few successful studies have focussed on developing a practice framework for differentiated instruction. Stanford and Reeves (2009) conducted a study that compared differentiating instruction through two different frameworks, Retrofitting the Curriculum and Universally Designing the curriculum for Learning (UDL). Retrofitting the curriculum is reactive instead of proactive-it has been a traditional response to differentiating instruction as a consequence of a lack of student progress. The process of retrofitting aims to find a solution after the curriculum has been planned and taught, and where students are not experiencing success. It forces learners to fit into the existing program, even though it might be entirely unsuitable for the student. As an alternative to retrofitting, UDL encourages teachers to plan for the success of their students instead of reacting when they fail. UDL embraces all learners by having teachers collect information about their students and then design instruction based on student requirements and interests (Stanford \& Reeves, 2009).

A study undertaken by Rock et al. (2008) produced in a practice framework known as REACH, which has five components: 1) Reflecting on will and skill; 2) Evaluating the curriculum; 3) Analysing the learners; 4) Crafting research-based lessons; and, 5) Honing in on the data. The REACH framework embraces many of the concepts and practices outline in the first part of this article as outlined below.

1. Reflecting on will and skill asks the teacher to consider their readiness for providing differentiated instruction and what is needed to change their classroom practice. This reflection could involve seeking resources to improve their knowledge base, 
critically reviewing the methods that they most commonly use, and acknowledging any misgivings around differentiated instruction. Such reflection may, in turn, change the beliefs and attitudes of the teachers towards differentiated instruction, which can lead to improved self-efficacy (Cross, 2009).

2. Evaluating the curriculum requires teachers firstly to identify critical content and 'big ideas' to teach (see e.g., Chalmers et al. (2017) for big ideas in the Australian Curriculum: Mathematics). Secondly, teachers need to gain an understanding of what their students already know and what formative assessment provides or contributes to such understanding, thus avoiding the teaching of unnecessary content and streamlining the curriculum to suit their students' needs (Andersson \& Palm, 2017).

3. Analysing the learners does not focus on what the students already know, but instead on gaining specific information about each student-students of the same age vary significantly in their life circumstances and experiences and these differences can have a significant impact on their readiness to learn (Tomlinson, 2014). Teachers need to analyse their group of students with a lens on readiness, interests, preferences, strengths, and needs with consideration of: "Which students are on an individualised learning plan?"; "Who is likely to need enrichment?"; and, "Which students will most likely need supplementary instruction?". The teacher can then decide whether to group their students for instruction based on curricula or on organisational needs (Rock et al., 2008).

4. Crafting research-based lessons requires instructors to ensure that, despite the area of instruction, students can enter at their performance level. For the students to be able to participate in the instruction at differing ability levels, the teacher needs to examine the complexity of the task and determine if there are sufficient opportunities for all students to participate at different levels, both cognitively and physically (Rock et al., 2008). Providing students with access to the task at any level recognises and promotes the individual abilities of each student, which nurtures inclusiveness and allows the student to feel like a valued and respected member of the class community (Tomlinson, 2014).

5. Honing in on the data outlines how the teacher responds to data, including results from formative assessment, is critical in differentiating instruction (see e.g., Andersson \& Palm, 2017). Teachers need to make data-driven decisions about students' learning and should routinely analyse not only student-performance data but also look critically at their teacher behaviour in order to make sound instructional decisions (McTighe \& O'connor, 2005).

\section{A Way Forward: The Design-Based Implementation Research (DBIR) Approach}

Many professional learning approaches may not serve in a sustainable way to change teaching practice to teachers in any longterm change process (Bobis et al., 2020; Bui et al., 2020; Kelly et al., 2018). An important consideration in engaging teacher in collaborative co-development processes is a regime that engages iterative learning and feedback, and which opens the way for use of a variety of approaches and different world views and assumptions.

DBIR retains many elements of conventional design research approaches, such as the use of iterative analysis to support incremental changes in teaching programs and practices, and also supports the flexible world view of pragmatism through feedback from collaboration and practical problem-solving (Fishman et al., 2013; Penuel et al., 2016; Woolcott et al., 2019c). As an emerging approach to innovation, DBIR can be positioned within a range of educational classrooms settings (both face-to-face and online), and its strong relationship to theoretical frameworks, such as policy research, blended learning, and action research, situates the DBIR approach within a number of educational research and practice contexts and methods (Fishman et al., 2013). As well, DBIR aligns with approaches and models that create and examine improved and sustainable infrastructure to support educational research and its application in scalable learning environments (Anderson et al., 2018).

Despite DBIR being a comparatively new approach, with a relatively small body of related literature, the approach engages four fundamental principles that define its benefits in educational settings (Fishman et al., 2013). These principles direct a DBIR initiative to broaden the steps required to identify and develop evidence related to implementation and implement innovations that can be scaled to suit specific learner groups in unique ways. The following section, summarised from Fishman et al. (2013, p. 136) and Woolcott et al. (2019c) outlines how these principles might be applied in the context of innovation in mathematics learning that focuses on building a gap between theory and practice.

1. Focus on persistent problems of practice from multiple stakeholders' perspectives: In DBIR, multiple stakeholders are formed into teams to identify practical problems that focus on research and development. Mathematics teachers can undertake professional learning experiences, for example, in teams that have differing socio-cultural perspectives and differing ideas about the importance of differentiated instruction in mathematics.

2. Improve practice with teams committed to iterative, collaborative design: The focus of DBIR, as with other forms of iterative collaborative initiatives, is on people working pragmatically to develop and test processes and methods aimed at improvement through iteration of teaching and learning within specific subject areas and their settings. The iteration embedded in DBIR should involve collaborative decisions around who will participate in the study's design, the design processes, and what evidence will form the basis for any required changes in the implementation. DBIR, like it's antecedent designed-based research, is aimed at developing support for implementing innovation that seeks to improve learning environments within classrooms (Penuel et al., 2016). However, DBIR adds an extra dimension by capturing team changes through iterative design cycles that can change the overall direction, including addressing changes in theory and methodology (Woolcott et al., 2019c).

3. Undertake a systematic inquiry that develops both theory and knowledge concerning classroom learning and implementation: The DBIR approach seeks to systematically develop both theory and knowledge systems that are useful across various classroom learning and implementation settings-this feature separates DBIR from most other design-based research. The approach, given its specific relation to design objects, encompasses learning theories within and across subject matter domains, informal or everyday learning, teacher learning, organisational change, and leadership. These theories can potentially 
shape the application of current policy research in mathematics education in Australia-as a by-product of using DBIR-to develop ways of improving student learning in mathematics (Woolcott et al., 2021).

4. Develop a capacity for sustaining change: DBIR commonly considers improvements to human capital, which in this study is related to developing mathematics teachers' capability in differentiating instruction. However, while DBIR may have a primary focus on improving human capital (Fishman et al., 2013), there is also a focus on building the entire system's capacity to implement, scale, and sustain innovations (Bui et al., 2020). The DBIR approach, therefore, supports researchers' inclusion as valid, individual participants, and research organisations, such as universities, as essential components of the ecology of supports that need to be improved to enhance and preserve excellence and equity within systems.

\section{Adapting DBIR to Complex Educational Contexts}

Applying a DBIR approach to a study of differentiated instruction in the secondary mathematics classroom may seem straightforward, but educational contexts may be dynamic and complex, rather than linear, simple or complicated (Davis \& Sumara, 2014; Hager \& Beckett, 2019; Koopmans \& Stamovlasis, 2016). The broader study context (from which this article is drawn) draws together educational researchers, classroom teachers, school administrators and classroom students in a way that relates to community need, both within the school and in the broader community of carers, parents, relatives and other interested parties (Bui et al., 2020; Lynch et al., 2020; Woolcott et al., 2021). A number of studies have determined that such study contexts, including mathematics classroom contexts, are, in and of themselves, complex systems (Davis \& Renert, 2013, Jörg et al., 2007; Steenbeek \& van Geert, 2013).

As well as offering a way of determining and describing complex educational contexts, complexity theory offers a novel viewpoint on collaboration in a diverse range of such contexts (Garner \& Kaplan, 2019; Hager \& Beckett, 2019; Koopmans \& Stamovlasis, 2016). At the same time, complexity thinking provides for the innovative and creative outcomes that may not necessarily occur in collaborative interventions that are defined by solution rather than effect (Jörg, 2017; Sandfort, 2018). A particular feature of maintaining interventions in complex educational environments is the establishment of boundary systems using project priorities and goals-collaborative decision-making that remains consistently within these boundaries can be effective in determining productive and goal-oriented implementation that is both effective and efficient, but which allows for emergent variation and its evaluation (Gilstrap, 2020; Woolcott et al., 2020; Zhang \& Ahmed, 2020).

Emergent behaviours in complex systems interventions are defined by the intervention rules, the project priorities and goals that define the intervention, that act as boundaries for a complex creative space (Davis \& Samara, 2014; Woolcott et al., 2020). In a study which engages co-development, such as that envisaged in the current article, such boundaries can be determined collaboratively ensuring that agency and intentionality, whether individual or shared, are recognised as equitable (see e.g., Tomasello, 2014). One of the ways to do this is by way of distributed pedagogical leadership that uses "generative dialogue as a tool with which management and personnel can better operate in the increasingly turbulent world of education...a way to negotiate in this [professional learning] realm in generating new knowledge and understanding." (Jäppinen \& Sarja, 2012, p. 64).

A number of DBIR initiatives, as it turns out, have described intervention processes undertaken in complex educational environments, including interventions at local, state, national levels and global levels (Gallagher \& Fazio, 2017; Sandfort, 2018; Sasson \& Miedijensky, 2020), where the: "complexity of any school context requires a shift in focus from teachers' learning at an individual level to learning and change at an organisational level.” (Jesson \& Spratt, 2017, p. 37). The current article, therefore, argues for consideration of complexity theory in determining whether the study contexts are complex (dynamical) systems, as educational contexts are increasingly understood to be (Koopmans \& Stamovlasis, 2016). A recent study of initial teacher education research in mathematics and science (Woolcott et al., 2020) reports on protocol that can be used, within the iterative processes of DBIR, to determine and describe accurately, and then account for, any such complexity. Once the parameters of any complex system are determined and described, including any boundary conditions, this protocol directs attention to examining complex system features such as emergent unpredictability and variation (Davis \& Sumara, 2014), in addition to other features already noted as significant in DBIR approaches (Penuel et al., 2016; Woolcott et al., 2019a).

\section{Generative Dialogue}

The very essence of teaching is focused on conversation or dialogue and, in our increasingly diverse world and its allowance for greater access to stored records of human spoken and written interactions, contemporary schooling should provide a context for rich, fruitful discourse. Despite this imperative, quality and sustained discussion between teachers and school leaders on teaching and learning issues is, in fact, rare (Adams et al., 2019; Petta et al., 2019). Generative dialogue is a tool suitable for guiding collaboratively developed practices, set within the DBIR approach, that can contribute to a teacher's ability to develop and successfully implement differentiation strategies for a diverse mathematics classroom. The ultimate aim of any effort to engage in conversation within professional practice is to step beyond mere traditional discussion, or even debate, and to achieve a higher level of 'reflective discourse' and, preferably, to 'generative dialogue' (Shields \& Edwards, 2005). Considering dialogue as generative draws on the Socratic tradition (Hardjono \& van Kemenade, 2021; Stelmach, 2020), with generative dialogue instantiating as a complex, interpersonal relationship that facilitates trust, loyalty, and mutual respect between professional educators (Davis, 2012).

In terms of complexity, generative dialogue can be applied to generating common frames of thinking, meanings that emerge from shared agency and intentionality, and a collective world view perhaps typical of a pragmatism paradigm (Jäppinen \& Sarja, 2012). As such, generative dialogue can build and maintain organisational learning while creating expanded and/or emergent opportunities for collaboration, acknowledgement, and celebration (Adams et al., 2019). 


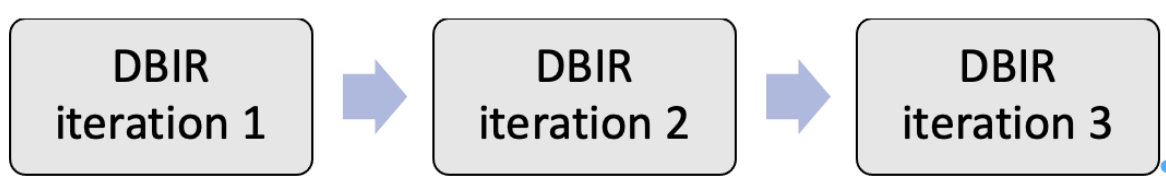

\begin{tabular}{|l|l|l|}
\hline $\begin{array}{l}\text { Establish initial } \\
\text { boundary } \\
\text { conditions }\end{array}$ & $\begin{array}{l}\text { Confirm or alter } \\
\text { boundary } \\
\text { conditions } \\
\text { Formulate question } \\
\text { for generative } \\
\text { dialogue }\end{array}$ \\
$\begin{array}{l}\text { Collaborative } \\
\text { reflection on or reformulate } \\
\text { evidence collected }\end{array}$ & $\begin{array}{l}\text { Keep } \\
\text { question for } \\
\text { generative dialogue } \\
\text { Collaborative } \\
\text { reflection on new } \\
\text { evidence collected }\end{array}$ \\
\hline
\end{tabular}

Figure 1. The overall DBIR process and its whole-school application using complexity thinking. The diagram illustrates the first three potential iterations.

Petta et al. (2019) argue, additionally, that the process of generative dialogue empowers educators and school leaders to be open to partnering with each other, regardless of positional power, and to do so in a spirit of mutual respect and trust. Disregarding positional power is highly relevant in the current study, where a researcher may potentially hold a position of leadership within the study setting (for example, as a Head of Department). Another advantage in using generative dialogue is its in-built motivational value for teachers in offering ownership and empowerment in a professional context (Adams et al., 2019; Petta et al., 2019).

While the DBIR approach has much to offer in the way of a sustained renewal process, both in-school and across systems, the approach was not designed to address the well-documented issues that so often arise in addressing teacher motivation (Brezicha et al., 2020; Hallinger \& Kulophas, 2020), including in mathematics teaching practice (Osman \& Warner, 2020). The introduction of generative dialogue, however, can build and maintain organisational learning as it creates new knowledge and empowers participants' future professional actions. The openness and accessibility of the dialogue process keeps all parties focused and dedicated (Townsend \& Adams, 2009) - in other words, its noteworthy feature is that it opens up a common ground for different ways of knowing and, at the same time, ensures the timely and ethical use of new information generated by the process (Petta et al., 2019).

\section{Outlining the Practice Framework}

The two parts of this article bring together the theory and practice of differentiated instruction, exemplified in a context of secondary mathematics teaching. The following section outlines a prototype practice framework for teachers that combines and consolidates that theory and practice in terms of an iterative DBIR approach. The framework is in two parts, with the first outlining the overall process of establishing the boundary conditions (using complexity thinking), determining a generative dialogue question and subsequent collaborative reflection on evidence collected (see Figure 1). These boundary conditions are guides for teacher question-making and reflection and serve to move teams towards collaborative consensus in initial and subsequent iterations.

The second part of the framework (Figure 2) is outlined as an initial step to assist teachers in co-developing and implementing strategies for differentiated instruction in the first and subsequent iterations. It is expected that participating teachers will codevelop and provide feedback on this initial framework and the effectiveness of its potential implementation in their classrooms. Teachers will then use the generative dialogue processes to further refine and re-develop the second part of the framework in line with their ongoing needs and resources.

The framework is designed for operation in a whole-school setting (Ohi et al., 2019), where teachers can find context-specific ways to implement differentiated instruction that best fits the local system context of the school classroom environment (Bui et al., 2020). In so doing, teachers can leverage student learning and professional learning interactions to enact opportunities that support their intention and agency when utilising generative dialogue. The framework, therefore, embraces the three critical components of whole-school approaches of Borda (2018, p. 48): "I. Whole-school vision; II. Tools to translate vision into practice; and III. Ongoing, collaborative teacher learning". Hence, the boundary conditions should include the school vision and operational aspects specific to the school's local system context, including how the school reflects the needs and aspirations of the community.

Although there may be a number of different sets of boundary conditions, for example, school policy, teacher professional standards and ethical research agreements, the second part of the framework (Figure 2) has a specific set of outer set of boundary conditions based in the REACH principles of Rock et al. (2008). These conditions govern the objectives of the project, providing discussion parameters for decision-making in each DBIR iteration, and in cycles within each iteration if needed. The principles advocated in Rock et al. (2008) provide a well-tested combination of the principles, beliefs and concepts suggested from the studies above related to curriculum differentiation and student learning as well as PCK, teacher efficacy, formative assessment, 


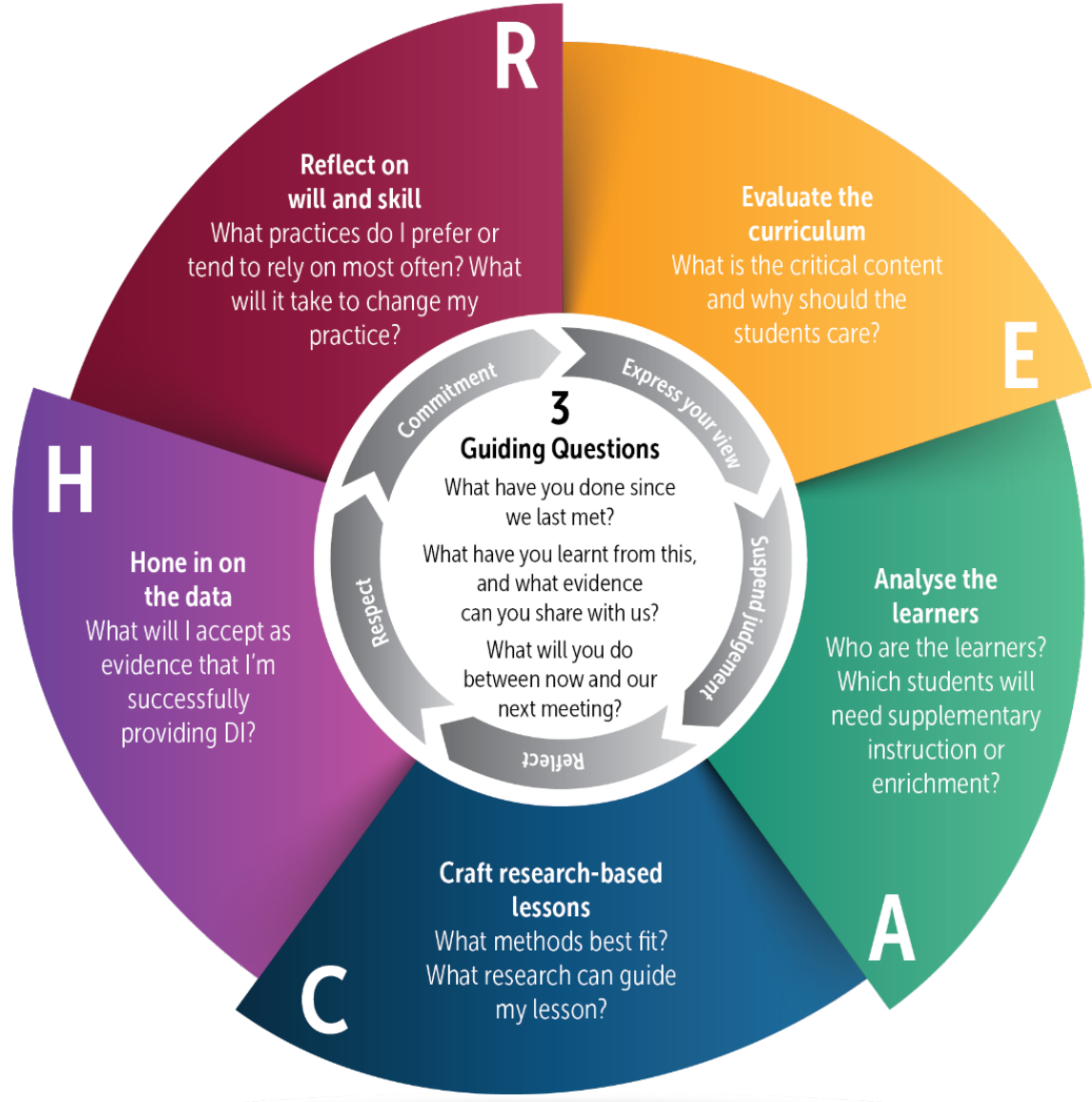

Figure 2. A practice framework for differentiated instruction. Adapted from Rock et al. (2008) and Adams et al. (2019).

teacher confidence and competence and professional learning (e.g., Bleakley et al, 2021; Bobis et al., 2020; Cross, 2009; DarlingHammond, 2010; Dixon et al., 2014; Stanford \& Reeves, 2009; Tomlinson, 2003, 2014; Valiandes \& Neophytou, 2018; Wiliam, 2011).

The framework also has an inner set of boundary conditions that form the basis for feedback from generative dialogue specifically, based on a list the key features of generative dialogue in Adams et al. (2019), where all participants:

- respect one another and establish internal ownership of both the process and its outcomes-mutual respect and trust encourage participants to engage in the process and form partnerships that are most likely to improve their professional practice;

- are encouraged to be involved and to remain committed, with their integrity and responsibility taken for granted;

- are encouraged to express their views and share their ideas;

- suspend any judgement and critique, and also use no gratuitous praise or fault, committing them to be constructive and effective listeners;

- focus on reflection by asking questions-reflective questioning can allow participants to refine aspects of their own experience and become conscious of the false conclusions, inconsistencies, origins, and implications of their thinking.

\section{Implementing the Framework}

It is anticipated that implementation of this framework will be centred around a series of regular teacher discussion groups, with an invited external expert, as part of the generative dialogue process. For example, a group might meet with a university researcher fortnightly for ten weeks. Each teacher would be asked initially to frame their guiding research question within the agreed practice framework for differentiated instruction. Since teachers will need some initial guidance as to relevant theory, the supplementary framework outlined in Figure $\mathbf{3}$ (and the cited literature) would provide them with a link between the theory and practice of differentiated instruction in developing a guiding question.

The framework highlights the issues that arose from the literature, such as professional learning, improving teacher efficacy, the role of formative assessment, and teacher confidence and competence. Accordingly, Figure 3 refers to the four DBIR principles of Fishman et al. (2013), the seven features of effective professional learning (Darling-Hammond, 2017), and the six key characteristics of an effective professional learning program (Valiandes \& Neophytou, 2018). Other elements of the outline the themes underpinning the successful implementation of differentiated instruction in the REACH principles of Rock et al. (2008), Tomlinson's (2014) four guiding principles of differentiated instruction and Wiliam's (2011) five teacher principles of formative assessment. 
DIFFERENTIATED INSTRUCTION UINKING THEORY WITH PRACTICE

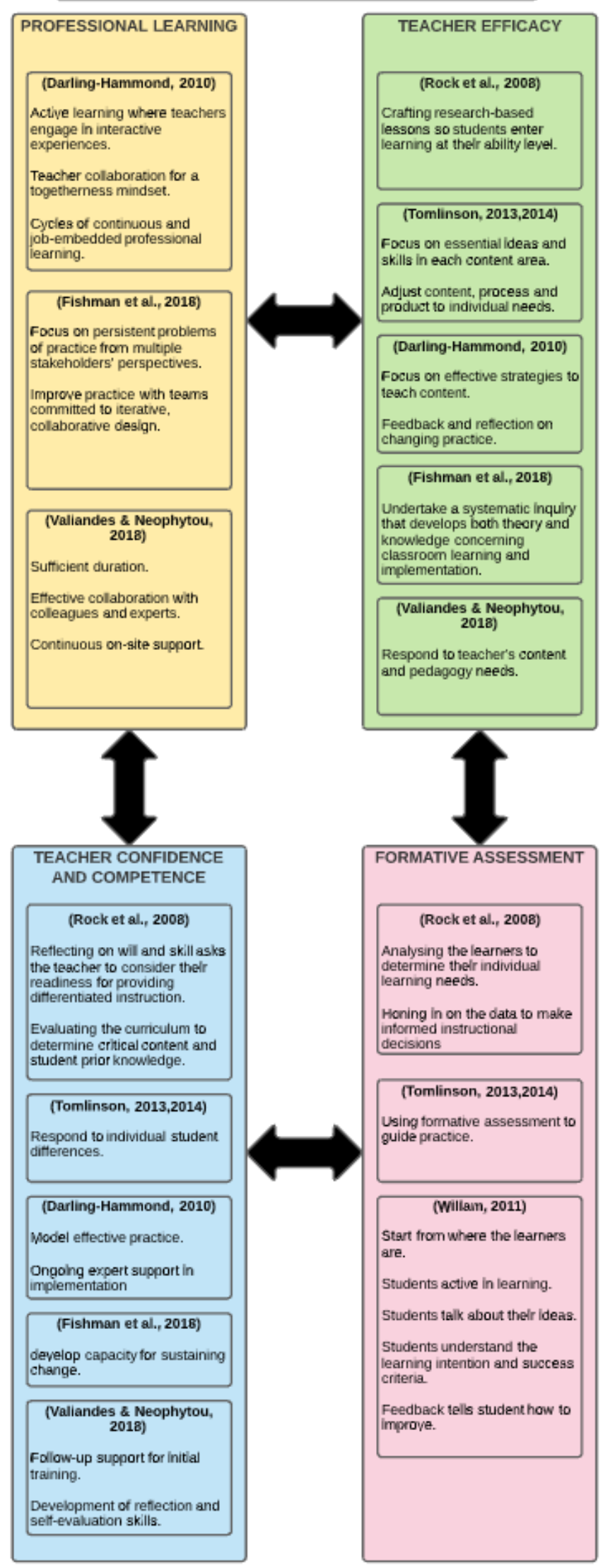

Figure 3. Differentiated Instruction: linking theory with practice. Adapted from Fishman et al. (2013), Darling-Hammond (2017), Valiandes and Neophytou (2018), Rock et al. (2008), Tomlinson (2014), and Wiliam (2011) 


\section{CONCLUSION}

Differentiated instruction plays a critical role in encouraging mathematics educators to move away from homogenous attainment grouping and towards heterogenous mixed-ability grouping. Mathematics teachers who actively participate in the research, design and implementation of a practice framework for differentiated instruction may find that such a framework helps to overcome the issues around PCK, self-efficacy and beliefs, and formative assessment, leading to improved confidence and competence. The framework provides a motivation as well as a strategy for teachers as active participants in their own professional learning by engaging collaboratively trialling and evaluating practices for differentiated instruction in their school context. This professional learning process should allow teacher knowledge and capacity to be developed on a 'whole-school' basis. The co-created and continuously developing framework should then contribute to an agreed shared practice of differentiating instruction in mathematics within the school.

The framework is currently being implemented as part of a broader project, Regional Teachers of Mathematics Networks (RTMN), being undertaken in Australia conjointly by Southern Cross University and the Mathematical Association of New South Wales (Woolcott et al., 2021). The process outlined in this article has implications, therefore, for wider use in professional learning more generally. Provided the efficacy and applicability of the framework for secondary mathematics teachers in whole-school contexts is established, the framework is likely then to be applicable to developing differentiated instruction in other teaching disciplines and at a variety of teaching levels, including in elementary schools. This application could be in any subject areas that might share similar challenges, especially in these times of enormous social and educational upheaval due to COVID-19. The framework, therefore, offers a way to revitalise and transform teaching and learning for mixed-ability groupings, benefitting both teachers and students, and provide flow-on benefits to the wider education community.

Author contributions: All authors have sufficiently contributed to the study, and agreed with the results and conclusions.

Funding: No funding source is reported for this study.

Declaration of interest: No conflict of interest is declared by authors.

\section{REFERENCES}

Adams, P., Mombourquette, C., \& Townsend, D. (2019). Leadership in education: The power of generative dialogue. Canadian Scholars.

Andersson, C., \& Palm, T. (2017). The impact of formative assessment on student achievement: A study of the effects of changes to classroom practice after a comprehensive professional development programme. Learning and Instruction, 49, 92-102. https://doi.org/10.1016/j.learninstruc.2016.12.006

Andersson, C., \& Palm, T. (2018). Reasons for teachers' successful development of a formative assessment practice through professional development - a motivation perspective. Assessment in Education: Principles, Policy \& Practice, 25(6), 576-597. https://doi.org/10.1080/0969594X.2018.1430685

Australian Mathematical Sciences Institute [AMSI]. (2020). The state of mathematical sciences 2020: $7^{\text {th }}$ discipline profile of mathematics and statistics in Australia. AMSI. https://amsi.org.au/wp-content/uploads/2020/05/amsi-discipline-profile2020.pdf

Bada, S. O. (2015). Constructivism learning theory: A paradigm for teaching and learning. Journal of Research \& Method in Education, 5(6), 66-70. https://doi.org/10.9790/7388-05616670

Ball, D. L., Thames, M. H., \& Phelps, G. (2008). Content knowledge for teaching: What makes it special. Journal of Teacher Education, 59(5), 389-407. https://doi.org/10.1177/0022487108324554

Bandura, A. (1977). Self-efficacy: Toward a unifying theory of behavioral change. Psychological Review, 84(2), $191-215$. https://doi.org/10.1037/0033-295X.84.2.191

Banks, J. A. (2007). Multicultural education: Characteristics and goals. In J. A. Banks, \& C. A. McGee Banks (Vol. Eds.), Multicultural education: Issues and perspectives: Vols. 3-32. John Wiley and Sons.

Barab, S., \& Squire, K. (2004). Design-based research: Putting a stake in the ground. The Journal of the Learning Sciences, 13(1), 114.

Bennett, R. E. (2011). Formative assessment: A critical review. Assessment in Education: Principles, Policy \& Practice, 18(1), 5-25. https://doi.org/10.1080/0969594X.2010.513678

Beswick, K., \& Fraser, S. (2019). Developing mathematics teachers' 21st century competence for teaching in STEM contexts. ZDM, 51(6), 955-965. https://doi.org/10.1007/s11858-019-01084-2

Black, P. (2015). Formative assessment-an optimistic but incomplete vision. Assessment in Education: Principles, Policy \& Practice, 22(1), 161-177. https://doi.org/10.1080/0969594X.2014.999643

Bleakley, J., Woolcott, G., Yeigh, T., \& Whannell, R. (2021). Developing emotional literacy in novice teachers using an affect-based reflection protocol. Australian Journal of Teacher Education, 45(10), 55-72.

Boaler, J. (1997). Experiencing school mathematics: Traditional and reform approaches to teaching and their impact on student learning. Lawrence Erlbaum. 
Boaler, J., \& Staples, M. (2008). Creating mathematical futures through an equitable teaching approach: The case of Railside School. Teachers College Record, 110(3), 608-645. https://www.tcrecord.org/

Boaler, J., Wiliam, D., \& Brown, M. (2000). Students' experiences of ability grouping - disaffection, polarisation and the construction of failure. British Educational Research Journal, 26(5), 631-648. https://doi.org/10.1080/713651583

Bobis, J., Way, J., Attard, C., Anderson, J., McMaster, H., \& Cartwright, K. (2020). Teachers' professional learning and development in mathematics education. In J. Way, C. Attard, J. Anderson, J. Bobis, H. McMaster \& K. Cartwright (Eds.), Research in Mathematics Education in Australasia 2016-2019 (pp. 117-146). Springer. https://doi.org/10.1007/978-981-15-4269-5_6

Bond, E., Woolcott, G., \& Markopoulos, C. (2020). Why aren't teachers using formative assessment? What can be done about it? Assessment Matters, 14, 112-136. https://doi.org/10.18296/am.0046

Borda, E., Warren, S., Coskie, T. L., Larson, B. E., Hanley, D., \& Cohen, J. (2018). Cross-disciplinary, whole school education reform in secondary schools: Three critical components. School-University Partnerships, 11(1), 46-56. https://eric.ed.gov/?id=EJ1179959

Boyle, B., Lamprianou, I., \& Boyle, T. (2005). A longitudinal study of teacher change: What makes professional development effective? Report of the second year of the study. School effectiveness and school improvement, 16(1), 1-27. https://doi.org/10.1080/09243450500114819

Brezicha, K. F., Ikoma, S., Park, H., \& LeTendre, G. K. (2020). The ownership perception gap: Exploring teacher job satisfaction and its relationship to teachers' and principals' perception of decision-making opportunities. International Journal of Leadership in Education, 23(4), 428-456.

Brooks, J. G., \& Brooks, M. G. (1999). In search of understanding: The case for constructivist classrooms. Association for Supervision and Curriculum Development.

Bruner, J. S. (1984). In search of mind: Essays in autobiography. Harper Collins.

Bui, V., Woolcott, G., Peddell, L., Yeigh, T., Ellis, D., Lynch, D. L., Willis, R., \& Samojlowicz, D. (2020). An online support system for teachers of mathematics in regional, rural and remote Australia. Australian and International Journal of Rural Education, 30(3), 69-88. https://www.journal.spera.asn.au/index.php/AIJRE/article/view/287

Chalmers, C., Carter, M. L., Cooper, T., \& Nason, R. (2017). Implementing "big ideas" to advance the teaching and learning of science, technology, engineering, and mathematics (STEM). International Journal of Science and Mathematics Education, 15(1), 25-43. https://doi.org/10.1007/s10763-017-9799-1

Cohen, E. G., \& Lotan, R. A. (2014). Designing groupwork: Strategies for the heterogeneous classroom third edition. Teachers College Press.

Cooper, B., Cowie, B., Furness, J. A., Peter, M., \& Bailey, J. (2017). Mathematical reasoning and knowledge in initial teacher education (MARKITE). Teaching \& Learning Research Initiative.

Cooper, R. (2007). An investigation into constructivism within an outcomes based curriculum. Issues in Educational Research, 17(1), 15-39. http://www.iier.org.au/

Cross, D. I. (2009). Alignment, cohesion, and change: Examining mathematics teachers' belief structures and their influence on instructional practices. Journal of Mathematics Teacher Education, 12(5), 325-346. https://doi.org/10.1007/s10857-009-9120-5

Darling-Hammond, L., Hyler, M. E., \& Gardner, M. (2017). Effective teacher professional development. Learning Policy Institute.

Davis, B. (2012). Educational reform, public engagement and "complexity". TCI (Transnational Curriculum Inquiry), 9(2), 50-66.

Davis, B., \& Renert, M. (2013). The math teachers know: Profound understanding of emergent mathematics. Routledge.

Davis, B., \& Sumara, D. (2014). Complexity and education: Inquiries into learning, teaching, and research. Routledge.

De Neve, D., Devos, G., \& Tuytens, M. (2015). The importance of job resources and self-efficacy for beginning teachers' professional learning in differentiated instruction. Teaching and Teacher Education, 47, 30-41. http://dx.doi.org/10.1016/j.tate.2014.12.003

Dillon, D. R., O'Brien, D. G., \& Heilman, E. E. (2000). Literacy research in the next millennium: From paradigms to pragmatism and practicality. Reading Research Quarterly, 35(1), 10-26. https://doi.org/10.1598/RRQ.35.1.2

Dixon, F. A., Yssel, N., McConnell, J. M., \& Hardin, T. (2014). Differentiated instruction, professional development, and teacher efficacy. Journal for the Education of the Gifted, 37(2), 111-127. https://doi.org/10.1177/0162353214529042

Doig, B., \& Groves, S. (2011). Japanese lesson study: Teacher professional development through communities of enquiry. Mathematics Teacher Education and Development, 13, 77-93. https://mted.merga.net.au/index.php/mted/article/view/47

Dweck, C. S. (2008). Mindsets and math/science achievement. Carnegie Corporation of New York, Institute for Advanced Study, Commission on Mathematics and Science Education.

Earl, L. M. (2012). Assessment as learning: Using classroom assessment to maximize student learning. Corwin Press.

Easterbrook, M. J., \& Hadden, I. R. (2021). Tackling educational inequalities with social psychology: Identities, contexts, and interventions. Social Issues and Policy Review, 15(1), 180-236. https://doi.org/10.1111/sipr.12070

Fishman, B. J., Penuel, W. R., Allen, A.-R., Cheng, B. H., \& Sabelli, N. (2013). Design-based implementation research: An emerging model for transforming the relationship of research and practice. National society for the study of education, 112(2), $136-156$.

Francis, B., Taylor, B., \& Tereshchenko, A. (2019). Reassessing 'ability' grouping: Improving practice for equity and attainment. Routledge. https://doi.org/10.4324/9780429436512 
Francome, T., \& Hewitt, D. (2020). "My math lessons are all about learning from your mistakes": How mixed-attainment mathematics grouping affects the way students experience mathematics. Educational Review, 72(4), 475-494.

Gallagher, T. L., \& Fazio, X. (2017). Design-based research: Professional learning and curricular integration. Sage. https://doi.org/10.4135/9781526419361

Gamoran, A. (2009). Tracking and inequality: New directions for research and practice (WCER working paper No. 2009-6). https://files.eric.ed.gov/fulltext/ED506617.pdf

Garner, J. K., \& Kaplan, A. (2019). A complex dynamic systems perspective on teacher learning and identity formation: An instrumental case. Teachers and Teaching, 25(1), 7-33. https://doi.org/10.1080/13540602.2018.1533811

George, P. S. (2005). A rationale for differentiating instruction in the regular classroom. Theory Into Practice: Differentiated Instruction, 44(3), 185-193. https://doi.org/10.1207/s15430421tip4403_2

Gess-Newsome, J. (2015). A model of teacher professional knowledge and skill including PCK. In A. Berry, P. Friedrichsen, \& J. Loughran (Eds.), Re-examining pedagogical content knowledge in science education (pp. 28-42). Routledge.

Gilstrap, D. L. (2020). Understanding persistence of at-risk students in higher education enrollment management using multiple linear regression and network analysis. The Journal of Experimental Education, 88(3), $470-485$. https://doi.org/10.1080/00220973.2019.1659217

Golding, J. (2017). Mathematics teachers' capacity for change. Oxford Review of Education, 43(4), 502-517. https://doi.org/10.1080/03054985.2017.1331846

Goos, M. (2016). Challenges and Opportunities in teaching mathematics. Australian Mathematics Teacher, 72(4), 34-38. https://eric.ed.gov/?id=EJ1121322

Goos, M., Bennison, A. \& Proffitt-White, R. (2018). Sustaining and Scaling up Research-Informed Professional Development for Mathematics Teachers. 20(2), 133-150.

Graven, M. (2004). Investigating mathematics teacher learning within an in-service community of practice: The centrality of confidence. Educational Studies in Mathematics, 57, 177-211. https://doi.org/10.1023/B:EDUC.0000049277.40453.4b

Gregory, G. H., \& Chapman, C. (2013). Differentiated instructional strategies: One size doesn't fit all. Corwin Press.

Hackenberg, A. J., Creager, M., \& Eker, A. (2020). Teaching practices for differentiating mathematics instruction for middle school students. Mathematical Thinking and Learning, 1-30. https://doi.org/10.1080/10986065.2020.1731656

Hager, P., \& Beckett, D. (2019). The emergence of complexity: Rethinking education as a social science. Springer Nature. https://doi.org/10.1007/978-3-030-31839-0

Hallinger, P., \& Kulophas, D. (2020). The evolving knowledge base on leadership and teacher professional learning: A bibliometric analysis of the literature, 1960-2018. Professional Development in Education, 46(4), 521-540. https://doi.org/10.1080/19415257.2019.1623287

Hardjono, T., \& van Kemenade, E. (2021). The emergence paradigm in quality management. Springer. https://doi.org/10.1007/9783-030-58096-4

Harrison, J., \& Yaffe, E. (2009). Teacher educators and reflective practice. In A. Swennen \& M. van der Klink (Eds.), Becoming a teacher educator (pp. 145-161). Springer. https://doi.org/10.1007/978-1-4020-8874-2_11

Hatlevik, I. K. R. (2017). The impact of prospective teachers' perceived competence on subsequent perceptions as schoolteachers. Teachers and Teaching, 23, 810-828. https://doi.org/10.1080/13540602.2017.1322056

Hawkey, K. (2006). Emotional intelligence and mentoring in pre-service teacher education: A literature review. Mentoring \& Tutoring, 14, 137-147. https://doi.org/10.1080/13611260500493485

He, Y., \& Levin, B. B. (2008). Match or mismatch? How congruent are the beliefs of teacher candidates, cooperating teachers, and university-based teacher educators? Teacher Education Quarterly, 35(4), 37-55. https://www.jstor.org/

Hill, H. C., Ball, D. L., \& Schilling, S. G. (2008). Unpacking pedagogical content knowledge: Conceptualizing and measuring teachers' topic-specific knowledge of students. Journal for Research in Mathematics Education, 39(4), 372-400. https://www.jstor.org/stable/40539304

Hodgen, J. \& Wiliam, D. (2006). Mathematics inside the black box: Assessment for learning in the mathematics classroom. GL Assessment.

Ireson, J., Clark, H., \& Hallam, S. (2002). Constructing ability groups in the secondary school: Issues in practice. School Leadership \& Management, 22(2), 163-176. https://doi.org/10.1080/1363243022000007737

Jäppinen, A. K., \& Sarja, A. (2012). Distributed pedagogical leadership and generative dialogue in educational nodes. Management in Education, 26(2), 64-72. https://doi.org/10.1177/0892020611429983

Jaremus, F., Gore, J., Fray, L., \& Prieto-Rodriguez, E. (2020). Grouped out of STEM degrees: The overlooked mathematics 'glass ceiling' in NSW secondary schools. International Journal of Inclusive Education, 1-17. https://doi.org/10.1080/13603116.2020.1776778

Jesson, R. N., \& Spratt, R. (2017). An Intervention in literacy in three Pacific nations: Implications of a context specific approach to co-design. International Education Journal: Comparative Perspectives, 16(1), 36-49. 
Johnston, O., \& Wildy, H. (2016). The effects of streaming in the secondary school on learning outcomes for Australian studentsA review of the international literature. Australian Journal of Education, 60(1), 42-59. https://doi.org/10.1177/0004944115626522

Jörg, T. (2017). On reinventing education in the age of complexity: A Vygotsky-inspired generative complexity approach. Complicity: An International Journal of Complexity and Education, 14(2), 30-53. https://doi.org/10.29173/cmplct29334

Jörg, T., Davisc, B. \& Nickmans, G. (2007). Towards a new, complexity science of learning and education. Educational Research Review, 2(2), 145-156. https://doi.org/10.1016/j.edurev.2007.09.002

Kalina, C., \& Powell, K. (2009). Cognitive and social constructivism: Developing tools for an effective classroom. Education, 130(2), 241-250. https://docdrop.org/static/drop-pdf/Powell-and-Kalina-U6g4p.pdf

Kalyuga, S. (Ed.). (2015). Instructional guidance: A cognitive load perspective. Information Age Publishing.

Kelly, N., Russell, N., Kickbusch, S., Barros, A., Dawes, L., \& Rasmussen, R. (2018). Online communities of teachers to support situational knowledge: A design-based study. Australasian Journal of Educational Technology, 34(5), $150-166$. https://doi.org/10.14742/ajet.3867

Koellner, K., \& Jacobs, J. (2015). Distinguishing models of professional development: The case of an adaptive model's impact on teachers' knowledge, instruction, and student achievement. Journal of Teacher Education, 66(1), 51-67. https://doi.org/10.1177/0022487114549599

Koopmans, M., \& Stamovlasis, D. (2016). Complex dynamical systems in education. Springer International Publishing. https://doi.org/10.1007/978-3-319-27577-2

Lerman, S. (2012). Articulating theories of mathematics learning. In Ernest, P. (Ed.), Constructing mathematical knowledge: Epistemology and mathematics education. Studies in Mathematics Education Series: 4 (pp. 41-49). Routledge.

Levy, H. M. (2008). Meeting the needs of all students through differentiated instruction: Helping every child reach and exceed standards. The Clearing House: A Journal of Educational Strategies, Issues and Ideas, 81(4), $161-164$. https://doi.org/10.3200/TCHS.81.4.161-164

Lunenburg, F. C. (2011). Critical thinking and constructivism techniques for improving student achievement. National Forum of Teacher Education Journal, 21(3), 1-9.

Lynch, D. L., Yeigh, T., Woolcott, G., Peddell, L., Samojlowicz, D., Hudson, S., Markopoulos, C., \& Willis, R. (2020). An innovative teacher of mathematics identity framework: An adaptive solution to systematic challenges facing teachers in regional, rural and remote Australia. Australian Mathematics Education Journal, 2(3), 16-22.

Marton, F. (1986). Phenomenography-a research approach to investigating different understandings of reality. Journal of Thought, 21(3), 28-49.

Mayer-Smith, J., \& Mitchell, I. (1997). Teaching about constructivism: Using approaches informed by constructivism. In V. Richardson (Ed.), Constructivist teacher education (pp. 135-152). Falmer Press.

McTighe, J., \& O'connor, K. (2005). Seven practices for effective learning. Educational Leadership, 63, $10-17$. https://old.bvsd.org/curriculum/Documents/Seven-Practices-for-Effective-Learning.pdf

Mijs, J. J. B. (2016). Stratified failure: Educational stratification and students' attributions of their mathematics performance in 24 countries. Sociology of Education, 89(2), 137-153. https:// doi.org/10.1177/0038040716636434

Moss, C. M., \& Brookhart, S. M. (2019). Advancing formative assessment in every classroom: A guide for instructional leaders. ASCD.

Murata, A. (2013). Diversity and high academic expectations without tracking: Inclusively responsive instruction. Journal of the Learning Sciences, 22(2), 312-335. https://doi.org/10.1080/10508406.2012.682188

Nichols, S. L., Schutz, P. A., Rodgers, K., \& Bilica, K. (2017). Early career teachers' emotion and emerging teacher identities. Teachers and Teaching, 23, 406-421. https://doi.org/10.1080/13540602.2016.1211099

Ohi, S., O'Mara, J., Arber, R., Hartung, C., Shaw, G., \& Halse, C. (2019). Interrogating the promise of a whole-school approach to intercultural education: An Australian investigation. European Educational Research Journal, 18(2), $234-247$. https://doi.org/10.1177/1474904118796908

Organization of Economic Co-operation and Development [OECD]. (2010). Educating teachers for diversity: Meeting the challenge. OECD.

Organization of Economic Co-operation and Development [OECD]. (2013). PISA 2012 Results: What Makes Schools Successful (Volume IV). OECD.

Organization of Economic Co-operation and Development [OECD]. (2018). Teaching for the future: Effective classrooms practices to transform education. OECD.

Osman, D. J., \& Warner, J. R. (2020). Measuring teacher motivation: The missing link between professional development and practice. Teaching and Teacher Education, 92, 103064. https://doi.org/10.1016/j.tate.2020.103064

Penuel, W. R., Fishman, B. J., Cheng, B. H., \& Sabelli, N. (2016). Organizing research and development at the intersection of learning, implementation, and design. Annual Review of Policy Design, 4(1), 1-10.

Petta, K., Smith, R., Chaseling, M., \& Markopoulos, C. (2019). Generative dialogue: A concept analysis. Management in Education, 33(2), 53-61. https://doi.org/10.1177/0892020618780978

Piaget, J. (1972). The Psychology of the Child. Basic Books. 
Raymond, K. (2018). M is not just for STEM: How myths about the purposes of mathematics education have narrowed mathematics curricula in the United States. Education Sciences, 8(2), 47. https://doi.org/10.3390/educsci8020047

Razer, M., Mittelberg, D., \& Ayalon, S. (2018). The ability-track glass ceiling of Israeli schooling: lessons from a comparative analysis of Israeli and Australian PISA 2012 data. International Journal of Inclusive Education, 22(2), $192-214$. https://doi.org/10.1080/13603116.2017.1362480

Rock, M. L., Gregg, M., Ellis, E., \& Gable, R. A. (2008). REACH: A framework for differentiating classroom instruction. Preventing School Failure: Alternative Education for Children and Youth, 52(2), 31-47. https://doi.org/10.3200/PSFL.52.2.31-47

Russell, T. (2005). Can reflective practice be taught?. Reflective Practice, 6(2), 199-204. https://doi.org/10.1080/14623940500105833

Sandfort, J. R. (2018). Theoretical foundations and design principles to improve policy and program implementation. In E. Stazky \& H. G. Frederickson (Eds.), Handbook of American Public Administration (pp. 475-496). Edward Elgar. https://doi.org/10.4337/9781786432070.00039

Sasson, I., \& Miedijensky, S. (2020). Transfer skills in teacher training programs: the question of assessment. Professional Development in Education, 1-38. https://doi.org/10.1080/19415257.2020.1839783

Schön, D.A. (1987). Educating the reflective practitioner. Jossey-Bass.

Schön, D.A. (Ed.) (1991) The reflective turn: Case studies in and on educational practice. Teachers College Press.

Shields, C. M., \& Edwards, M. M. (2005). Dialogue is not just talk: A new ground for educational leadership (Vol. 289). Peter Lang.

Shulman, L. S. (1986). Those who understand: Knowledge growth in teaching. Educational researcher, 15(2), 4-14. https://doi.org/10.3102/0013189x015002004

Shulman, L. S., \& Shulman, J. H. (2004). How and what teachers learn: A shifting perspective. Journal of Curriculum Studies, 36, $257-$ 271. https://doi.org/10.1177/0022057409189001-202

Siyepu, S. (2013). The zone of proximal development in the learning of mathematics. South African Journal of Education, 33(2). https://doi.org/10.15700/saje.v33n2a714

Smale-Jacobse, A. E., Meijer, A., Helms-Lorenz, M., \& Maulana, R. (2019). Differentiated instruction in secondary education: A systematic review of research evidence. Frontiers in Psychology, 10, 2366. https://doi.org/10.3389/fpsyg.2019.02366

Smets, W., De Neve, D., \& Struyven, K. (2020). Responding to students' learning needs: How secondary education teachers learn to implement differentiated instruction. Educational Action Research, 1-18. https://doi.org/10.1080/09650792.2020.1848604

Smit, R., \& Humpert, W. (2012). Differentiated instruction in small schools. Teaching and Teacher Education, 28(8), 1152-1162. https://doi.org/10.1016/j.tate.2012.07.003

Spillane, J. P., Diamond, J. B., \& Jita, L. (2003). Leading instruction: The distribution of leadership for instruction. Journal of Curriculum studies, 35(5), 533-543. https://doi.org/10.1080/0022027021000041972

Stanford, B., \& Reeves, S. (2009). Making it happen: Using differentiated instruction, retrofit framework, and universal design for learning. Teaching Exceptional Children Plus, 5(6), n6. https://files.eric.ed.gov/fulltext/EJ967757.pdf

Steenbeek, H., \& van Geert, P. (2013). The emergence of learning-teaching trajectories in education: A complex dynamic systems approach. Nonlinear Dynamics, Psychology, and Life Sciences, 17(2), 233-267.

Stelmach, B. (2020). [Review of the book Leadership in education: The power of generative dialogue, by P. Adams, C. Mombourquette, \& D. Townsend]. Canadian Journal of Educational Administration and Policy, 193, 143-146.

Stephanou, A., \& Lindsey, J. (2013). Progressive achievement tests in mathematics (PATMaths) (4th ed.). Australian Council for Educational Research (ACER) Press.

Sullivan, P., Bobis, J., Downton, A., Feng, M., Hughes, S., Livy, S., ... \& Russo, J. (2020). Threats and opportunities in remote learning of mathematics: implication for the return to the classroom. Mathematics Education Research Journal, 32, 551-559. https://doi.org/10.1007/s13394-020-00339-6

Suprayogi, M. N., Valcke, M., \& Godwin, R. (2017). Teachers and their implementation of differentiated instruction in the classroom. Teaching and Teacher Education, 67, 291-301. https://doi.org/10.1016/j.tate.2017.06.020

Sutton, R. E., \& Wheatley, K. F. (2003). Teachers' emotions and teaching: A review of the literature and directions for future research. Educational Psychology Review, 15(4), 327-358. https://doi.org/10.1023/A:1026131715856

Sweller, J., Ayres, P., \& Kalyuga, S. (2011). Cognitive load theory: Explorations in the learning sciences, instructional systems and performance technologies. Springer. https://doi.org/10.1007/978-1-4419-8126-4

Taylor, B., Francis, B., Archer, L., Hodgen, J., Pepper, D., Tereshchenko, A., \& Travers, M. C. (2017). Factors deterring schools from mixed attainment teaching practice. Pedagogy, Culture \& Society, 25(3), $327-345$. https://doi.org/10.1080/14681366.2016.1256908

Taylor, B., Hodgen, J., Tereshchenko, A., \& Gutiérrez, G. (2020). Attainment grouping in English secondary schools: A national survey of current practices. Research Papers in Education, 1-22. https://doi.org/10.1080/02671522.2020.1836517

Tereshchenko, A., Francis, B., Archer, L., Hodgen, J., Mazenod, A., Taylor, B., ... \& Travers, M. C. (2019). Learners' attitudes to mixedattainment grouping: Examining the views of students of high, middle and low attainment. Research Papers in Education, 34(4), 425-444. https://doi.org/10.1080/02671522.2018.1452962

Timperley, H. (2011). Realizing the power of professional learning. Open University Press. 
Tomasello, M. (2014). A natural history of human thinking. Harvard University Press. https://doi.org/10.4159/9780674726369

Tomlinson, C. A. (1999). Mapping a route toward differentiated instruction. Educational leadership, 57, 12-17.

Tomlinson, C. A. (2000). What is differentiated instruction. In C. M. Callahan \& H. L. Hertberg-Davis (Eds.), Fundamentals of gifted education: Considering multiple perspectives (pp. 287-300). Routledge.

Tomlinson, C. A. (2004). How to differentiate instruction in mixed ability classrooms (2nd ed.). ASCD.

Tomlinson, C. A. (2005). Grading and differentiation: Paradox or good practice? Theory Into Practice, 44(3), $262-269$. https://doi.org/10.1207/s15430421tip4403_11

Tomlinson, C. A. (2014). The differentiated classroom: Responding to the needs of all learners (2nd ed.). ASCD.

Tomlinson, C. A. (2016). The bridge between today's lesson and tomorrow's. In M. Scherer (Ed.), On formative assessment: Readings from educational leadership (pp. 14-23). ASCD.

Tomlinson, C. A. (2017). How to differentiate instruction in academically diverse classrooms (3rd ed.). ASCD.

Tomlinson, C. A., Brighton, C., Hertberg, H., Callahan, C. M., Moon, T. R., Brimijoin, K., Conover, L. A., \& Reynolds, T. (2003). Differentiating instruction in response to student readiness, interest, and learning profile in academically diverse classrooms: A review of literature. Journal for the Education of the Gifted, 27(2-3), 119-145. https://doi.org/10.1177/016235320302700203

Townsend, D., \& Adams, P. (2009). The essential equation: A handbook for school improvement. Detselig Enterprises.

Ültanır, E. (2012). An epistemological glance at the constructivist approach: Constructivist learning in Dewey, Piaget, and Montessori. International Journal of Instruction, 5(2), 195-212. http://www.e-iji.net/

United Nations Educational, Scientific and Cultural Organisation [UNESCO]. (2005). Guidelines for inclusion: Ensuring assess to education for all. UNESCO.

United Nations Educational, Scientific and Cultural Organisation [UNESCO]. (2015). EFA global monitoring report: Education for all 2000-2015: Achievements and challenges. UNESCO.

Valiandes, S., \& Neophytou, L. (2018). Teachers' professional development for differentiated instruction in mixed-ability classrooms: investigating the impact of a development program on teachers' professional learning and on students' achievement. Teacher Development, 22(1), 123-138. https://doi.org/10.1080/13664530.2017.1338196

Van der Kleij, F. M., Cumming, J. J., \& Looney, A. (2018). Policy expectations and support for teacher formative assessment in Australian education reform. Assessment in Education: Principles, Policy \& Practice, 25(6), 620-637. https://doi.org/10.1080/0969594X.2017.1374924

Vingsle, C. (2014). Formative assessment: Teacher knowledge and skills to make it happen thesis). Unpublished Licentiate thesis. Umeå University, Sweden. http://umu.diva-portal.org/smash/get/diva2:735415/FULLTEXT01.pdf

Von Glasersfeld, E. (1989). Cognition, construction of knowledge, and teaching. In M. R. Matthews (Ed.), Constructivism in science education (pp. 11-30). Springer. https://doi.org/10.1007/BF00869951

Vygotsky, L. S. (1978). Mind in society: The development of higher mental processes (E. Rice, Ed. \& Trans.). Harvard University Press.

Wheatley, K. F. (2005). The case for reconceptualizing teacher efficacy research. Teaching and Teacher Education, 21(7), 747-766. https://doi.org/10.1016/j.tate.2005.05.009

Wiliam, D. (2011). What is assessment for learning? Studies in Educational Evaluation, 37(1), 3-14. https://doi.org/10.1016/j.stueduc.2011.03.001

Willis, R., Lynch, D. L., Peddell, L., Yeigh, T., Woolcott, G., Bui, V., Boyd, W., Ellis, D., Markopoulos, C., \& James, S. (2021). Development of a teacher of mathematics identity (ToMI) scale. Mathematics Education Research Journal. https://doi.org/10.1007/s13394-021-00391-w

Woolcott, G., Leonard, S., Scott, A., Keast, R., \& Chamberlain, D. (2020). Partnered research and emergent variation: Developing a set of characteristics for identifying complexity in higher education partnerships. Journal of Higher Education Policy and Management. https://doi.org/10.1080/1360080X.2020.1733734

Woolcott, G., Peddell, L., Yeigh, T., Willis, R., Markopoulos, C., Ellis, D., Lynch, D., \& Bui, V. (2021). School reform in rural Australia: Developing adaptive solutions to systemic challenges for teachers of mathematics. In C. V. Meyers, \& M. J. Darwin (Eds.), Rural school turnaround and reform: It's hard work!. Information Age Publishers.

Woolcott, G., Scott, A., Norton, M., Whannell, R., Galligan, L., Marshman, M., Pfeiffer, L., \& Wines, C. (2017a). It's part of my life: Engaging university and community to enhance science and mathematics education. Final report for Enhancing the Training of Mathematics and Science Teachers. Department of Education and Training, Canberra, Australia.

Woolcott, G., Scott, A., Norton, M., Whannell, R., Galligan, L., Marshman, M., Pfeiffer, L., \& Wines, C. (2017b). The EnhancementLesson-Reflection process: A resource manual for science and mathematics learning and teaching. Companion Report to the Final report: It's part of my life: Engaging university and community to enhance science and mathematics education. Department of Education and Training, Canberra, Australia.

Woolcott, G., Seton, C., Mason, R., Chen, O., Lake, W., Markopoulos, C., \& Boyd, W. (2019a). Developing a new generation MOOC (ngMOOC): A design-based implementation research project with cognitive architecture and student feedback in mind. European Journal of Open, Distance and E-learning, 22(1). https://doi.org/:10.2478/eurodl-2019-0002 
Woolcott, G., Whannell, R., Wines, C., Pfeiffer, L., Marshman, M., \& Galligan, L. (2019b). Collaboration and co-creation in regional and remote education: Case studies from initial teacher education programs. The Australasian Journal of Regional Studies, 25(1), 54-80. Retrieved from https://www.anzrsai.org/assets/Uploads/PublicationChapter/AJRS-25.1-pages-054-to-080.pdf

York-Barr, J., Sommers, W., Ghere, G., \& Montie. J. (2006). Reflective practice to improve schools. Corwin Press.

Zhang B. H., \& Ahmed S. A. M. (2020). Systems thinking-Ludwig Von Bertalanffy, Peter Senge, and Donella Meadows. In B. Akpan \& T. J. Kennedy (Eds.), Science education in theory and practice (pp. 419-436). Springer Texts in Education. https://doi.org/10.1007/978-3-030-43620-9_28 